\title{
ORIENTE: TOWARDS A LITERARY GEOGRAPHY
}

\section{Peter Hulme (University of Essex)}

Caribbean Interfaces, ed. Lieven D’hulst et al., Amsterdam: Rodopi, 2007, pp. 153-168.

This paper is an early sketch of one part of a new collaborative project. The starting point for the larger project is a sense that the principal format for writing literary history over the last two centuries - based around nation and language - might be reaching exhaustion and that we need to investigate other possibilities. Increasing mobility and increasing awareness of past mobility have tended in recent years to undermine the exclusivity both of national and regional boundaries defined in the way the nation state would define them - by birth or later citizenship. In the Caribbean case, the threevolume History of Literature in the Caribbean edited by James Arnold and published by John Benjamins, the final volume of which appeared in 2001, provides what will remain for many years the definitive literary history written in the established format. ${ }^{1}$ Volume 3 of that History then offers one way forward towards a newer paradigm with its thematic and cross-cultural approach, perhaps the inauguration, as the editor suggests, of a new comparative literary history of the Caribbean. ${ }^{2}$ The "literary geography" in my title suggests a rather different (though not necessarily incompatible) approach, one which puts place first. This attention to place is not offered as the single approach now needed to write literary history, rather as one approach which might highlight different aspects from those featured in other approaches. In what follows I will outline briefly what some of the advantages might be of this attention to place and what kind of theory might support it, before offering a sketch of a case study of one particular place, Oriente, the east of Cuba. The full version of the collaborative project would aim to articulate at least twenty book-length projects with a view to establishing an extensive literary geography of the Caribbean.

\section{The attention to place}

If we are rethinking from first principles - which we need to do every so often - then we should not assume that "the Caribbean" is a self-evident region. Historically, there has been little agreement as to exactly which territories should be included beyond the Caribbean islands themselves. There are no absolutes here, no given or natural categories. However, from the point of view of cultural geography, it might be argued that the most logical region for wider analysis would stretch from, perhaps, Charleston, on the eastern seaboard of the United States, to Bahia, on the eastern seaboard of northern Brazil, incorporating the Caribbean littoral of Central America as well as the islands of the Caribbean sea, and including at least those portions of the southern USA and northern South America which received African slaves and built the plantations on which they laboured. In other words the region that the sociologist Charles Wagley described in 1960 as Plantation America, and which we might also think of as an extended Caribbean. ${ }^{3}$

Within this extended Caribbean region there are obviously very many different kinds of places. There are cities which have always acted as magnets: New Orleans, Havana, Cartagena. There are islands so small that they could not be further sub-divided into more than one place for these current purposes: Nevis, Barbuda, Roatán. There are geographical features that have the resonance to become places: the Orinoco delta, the Blue Mountains of Jamaica, the Louisiana bayous. There are even

\footnotetext{
${ }^{1}$ A History of Literature in the Caribbean, ed. A. James Arnold, Amsterdam/Philadelphia, 3 vols., 1994, 1997, and 2001.

${ }^{2}$ A History of Literature in the Caribbean, II, 5.

${ }^{3}$ See Charles Wagley, "Plantation America: A Culture Sphere”, in Caribbean Studies: A Symposium, ed. Vera Rubin, Seattle, 1960, 3-13. Variations on the idea were developed during the 1960s and 1970s, most significantly by Lloyd Best in 1967: Lloyd Best, “Independent Thought and Caribbean Freedom”, in Readings in the Political Economy of the Caribbean, ed. Norman Girwan and Owen Jefferson, Mona, Jamaica, 1971, 7-26 (originally published in New World Quarterly, III/4 (1967)). Useful summaries of these theories are in Cecilia Green, "Caribbean Dependency Theory of the 1970s: A Historical-Materialist-Feminist Revision”, in New Caribbean Thought: A Reader, ed. Brian Meeks and Folke Lindahl, Kingston, 2001, 40-72, and Antonio Gaztambide-Geigel, "La invención del Caribe en el siglo XX: las definiciones del Caribe como problema histórico y metodológico”, Revista Mexicana del Caribe, I/1 (1996), 75-96.
} 
political features that have similar resonance: the border between Haiti and the Dominican Republic, the border between Venezuela and Guyana, the Panama Canal zone. Oriente is probably at the larger end of the size spectrum for a place in this sense. Bigger places can obviously be further divided: Oriente has several cities and mountain-ranges and other features which could themselves constitute places for an even more detailed literary topography.

To write a literary history based on place is to suggest a different kind of attention to writing. These are some of the general features of an attention to place:

- If place determines, then the nationality and language of the writers involved are secondary: subject matter is paramount. The assumption has often been that a writer needs to be born in the Caribbean in order to be considered a Caribbean writer. That never did make much sense: authors like Raymond Breton, James Phillippo, and Alec Waugh spent large amounts of their lives in the Caribbean, wrote extensively about it, and should be taken seriously as contributing to Caribbean writing. Attention to place never asks to see a passport.

- A focus on place makes more visible connections between writing which shares a topography, whether that topography is seen as determining (on writers brought up within it and writing out of it) or whether the topography is described (by writers visiting from elsewhere). Travel writing certainly offers a rich seam which has been inadequately explored in literary histories.

- A focus on place is going to be particularly attentive to landscape in its widest sense, to the meanings of place, whether natural or architectural.

- Though always responsive to genre (as all literary history should be), a focus on place is more attentive than most literary history to non-fictional writing, to the chronicles and memoirs and autobiographies that are grounded in place. Arguably, Caribbean writing has suffered from being too often shoe-horned into the traditional European categories of novel, poem, play, and essay. That last category in particular hardly seems adequate to the variety and vibrancy of non-fictional writing in the Caribbean.

- Attention to place is probably better attuned to some genres than to others: to the realist novel, say, than to metaphysical poetry; but it avoids no form of writing that might have a topographical dimension - and arguably all writing has some. It certainly pays as much attention to region as to nation.

- Within geographical places are literary places (topoi): in the Caribbean, the great house, the traveller's hotel, the weather, the pleasant place (the classical locus amonus), the plantation, the map, the slave hut, the mine, the crop grounds, the indigenous reservation, the graveyard, the camp, the market. These topoi provide one set of grounds for comparison between different places.

- Attention to place always needs consideration alongside attention to trajectory. The Caribbean region has been characterised by an extraordinary range of voluntary and involuntary movements at least over the last five centuries. Beyond the variety of individual trajectories there are distinct patterns: from provincial city to metropolis - in the Cuban case the very resonant road from Santiago to Havana - or indeed from Havana to Santiago; but also those leading from Cap Haïtien to Santiago or from Baracoa to Boston, trajectories of exile or of commerce which always have cultural implications and consequences.

Attention to place is not new in literary studies. The work of Raymond Williams, especially his book The Country and the City, is an indispensable reference point. ${ }^{4}$ Attention to place also draws on recent work within cultural geography and environmental literary studies, and, in particular, on the work of Edward Casey in the history of philosophy, who has done a great deal to reintroduce the idea of place - as opposed to that of space - to contemporary thinking. Casey's basic argument is that, after Aristotle, the idea of place was slowly assimilated to that of space, a tendency which reached a climax in seventeenth-century physics with the "mathematization of nature", as Husserl termed it,

\footnotetext{
${ }^{4}$ Raymond Williams, The Country and the City, London, 1973.
} 
after which place came to be seen as the mere modification of space. Interestingly, Casey links this demotion of place with the era "in which the domination of native peoples was accomplished by their deplacialization: the systematic destruction of regional landscapes that served as the concrete settings for local culture". ${ }^{5}$ In general terms, then, the renewed attention to what he calls "vernacularity of place" ${ }^{6}$ can be seen as a postcolonial move, appropriate for the study of an area such as the Caribbean.

\section{Oriente in general}

Oriente is the eastern quarter of Cuba and for many years the name of the island's easternmost province. It includes the island's second city, Santiago de Cuba, as well as the significant provincial towns of Baracoa, Guantánamo, Bayamo, Puerto Príncipe, and Holguín. It also includes the US Naval Base at Guantánamo Bay, and the largest mountain ranges in Cuba, the Sierra Maestra and the Sierra del Cristal.

At the beginning of the sixteenth century Cuba was invaded from the east: its first Spanish city was Baracoa, on the eastern tip of the island. Fairly quickly, however, Havana, on the northwest coast, took over as the most significant city because of the importance of its harbour. From 1550 Havana was developed as one of key cities of the Spanish Empire in the Americas, becoming the capital of the island in 1607. By 1700 half the population of Cuba lived in Havana, leading to the relative neglect of the eastern part of the island, which became known simply as Oriente. Even during the development of sugar and tobacco plantations in the nineteenth century, the mountainous sierras of the east restricted economic development there, though smuggling remained rife and profitable. Havana has of course remained the capital city of Cuba after notional independence in 1898, and after the Cuban Revolution in 1959; and consequently therefore has remained the centre of Cuban political and cultural life. Travellers to Cuba have tended to visit Havana first and Oriente afterwards, if at all; except those drawn to Oriente for particular reasons, often to do with the revolutionary wars during the second half of the nineteenth century or during the 1950s.

Over the last five centuries, then, Cuban writers have gravitated to Havana, and most Cuban books have been published in Havana. But of course some Cuban writers have been born in Oriente and remained there (the poet Regino E. Boti offers an interesting case ${ }^{7}$ ), others have continued to write about it after leaving (such as Reinaldo Arenas ${ }^{8}$ ), others Cuban and non-Cuban have travelled to it and written about it, and Oriente and its component parts have had symbolic and mythic and ideological qualities attached to them.

Because of its terrain and its distance from Havana, Oriente has often been regarded as emblematic of el campo as opposed to the city, savagery as opposed to civilisation, backwardness as opposed to modernity. But the values attached to these dialectics can often be reversed: when the city, civilisation, and modernity become emblematic of colonialism, decadence, and corruption, then the countryside becomes the source of purity and renewal, a rôle it has increasingly played over the last 150 years because of the revolutionary initiatives begun there in 1878, 1895, and 1956.

The phenomenon of regionalism is one example of how places might often need conceiving dialectically: Oriente is in this sense not-Havana. But regionalism, developing in response to nationalism, is still defined by that of nationalism, whereas an attention to place is quite as open to global interests. Regionalism is often political inasmuch as its implicit claim is based on its grounding in the autochthonous realities of the country in opposition to a capital city supposedly too open to foreign goods and ideas, too quick to sell itself in some international marketplace. The moral dimension to this opposition is not alien to Cuban history. But attention to place is openly amoral: it observes the dialectic but has no investment in one side or the other. It is endlessly fascinated by the

\footnotetext{
${ }^{5}$ Edward S. Casey, The Fate of Place: A Philosophical History, Berkeley, 1997, xii.

${ }^{6}$ Casey, The Fate of Place, 77.

${ }^{7}$ Little known in his lifetime, Boti - who was born and lived all his adult life in Guantánamo - is now recognised as one of the most significant twentieth-century Cuban poets: see the recent collections of his work: La visita de los dioses (Selección de poesías de Regino E. Boti), Havana, 2004, and the bi-lingual Kindred Spirits: Poems by Regino E. Boti, ed. Stephen Hart, London, 2005.

${ }^{8}$ The landscape of Oriente features as a persistent image of lost innocence in works such as Antes que anochezca (1992).
} 
movement of people and ideas which swell onto the shores of its given place, for whatever reason and in whatever form they find expression.

Of the defining dialectics for Oriente, modernity and backwardness is perhaps the strongest, based on the actuality not only of the kind of development - financial, cultural, architectural - almost always associated with capital cities, but with the additional factor of Havana's hinterland seeing the location of the majority of the sugar plantations which drove the country's economic development during the nineteenth century. Oriente was not - as its equivalent was in many other countries - the rural region which saw the riches it produced syphoned off to support the parasite capital; it was the marginalised and neglected further reaches of the country which was home to sectors of the economy largely irrelevant to the processes of modernisation. It occupied a kind of third space; not even that to the this of Havana, but truly the other. ${ }^{9}$

The writing of Oriente has a long history. Almost archetypally for places subject to European attention, that history begins with two contrasting pieces of writing: Columbus's journal entries for November 1492, which he spent on the northern coast of Oriente, where he emphasises the beauty and fertility of the area; and the chapters in Bartolomé de Las Casas's Historia de Indias in which Las Casas, who served as a soldier in Cuba shortly after Diego Velázquez's entrada in 1511, describes the Spanish brutality against the Cuban natives which first pricked his conscience. If, as has been suggested, the literature of anti-imperialism begins with Las Casas, then it begins in Oriente with his accounts of Spanish soldiers chasing Indians into the sierras, a recurrent motif for the following 450 years. ${ }^{10}$

Three initial examples will suggest some of the particular resonances Oriente has held for outsiders, stressing its separateness from the rest of the island in general and from Havana in particular. Federico García Lorca’s poem, “Son de los negros en Cuba”, written during the six months he spent on the island in 1930, embodies the emblematic significance of Oriente with its incantatory line, "Iré a Santiago". It seems appropriate that there has been much discussion about whether Lorca actually did go to Santiago from his base in Havana, but what the poem expresses is not an actual intention but a fantasy desire for an ideal place, a landscape which - as one critic has suggested - combines a future utopia with the familiarity of the past. So, arriving in Cuba as he did from the dislocated modernity of New York, Lorca found in Havana a version of his homeland in the south of Spain but with added liberation from Spanish restrictions. But then came the realization that Havana was not Cuba, that the city might have too much of modernity about it, that the essence of the island was to be found elsewhere, in the perhaps darker and older pleasures of Santiago, of which the poet dreams and probably experienced for himself:

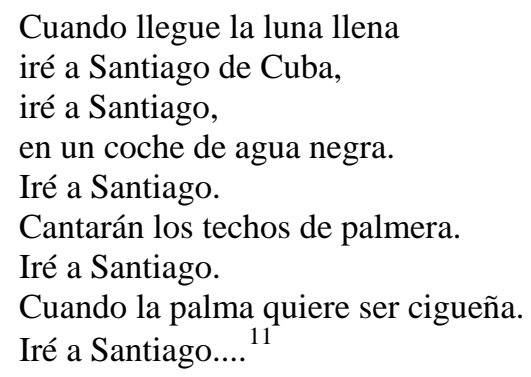

Many others had preceded Lorca, not least of course the US Army units that had entered the city in 1898. During the 1890s, the majority of the writing associated with Oriente was produced by reporters writing about Cuba's struggle for independence and then on US engagement in the war. Some significant figures, not least Stephen Crane, Theodore Roosevelt, and Máximo Gómez, left

\footnotetext{
${ }^{9}$ See John Barrell, The Infection of Thomas De Quincey: A Psychopathology of Imperialism, New Haven, 1991, 10.

${ }^{10}$ Christopher Columbus, The Diario of Christopher Columbus's First Voyage to America: 1492-93, ed. and trans. Oliver Dunn and James E. Kelley, Norman, 1989, 116-65, and Bartolomé de las Casas, Historia de las Indias [1559], ed. Agustín Millares Carlo, Mexico, 1981, II, 522-23.

${ }^{11}$ See Sarah Wright, “Dramatic Encounters: Federico García Lorca’s Trip to Cuba”, in Cultural Encounters: European Travel Writing in the 1930s, eds Charles Burdett and Derek Duncan, New York, 2002, 131-142.
} 
accounts of the fighting in Oriente. Along with Stephen Crane, the best-known US reporter in 1898 was Richard Harding Davis, who worked for William Randolph Hearst. But Davis knew Oriente well from an earlier visit which he had already drawn on for a best-selling novel called Soldiers of Fortune, published in 1897 in the run-up to the US invasion. What is particularly interesting about Soldiers of Fortune is that although generically a historical romance, it is actually grounded in very material and contemporary issues, not unconnected with US interest in this part of the island. Robert Clay, the hero of the novel, is an engineer from the US west working for a wealthy US entrepreneur. In a letter back to the States Clay writes about the place he’s visiting:

I saw great masses of red hematite lying exposed on the side of the mountain, only waiting a pick and shovel, and at one place there were five thousand tons in plain sight. I should call the stuff first-class Bessemer ore, running about sixty-three per cent metallic iron. The people know it is there, but have no knowledge of its value, and are too lazy to ever work it themselves. ${ }^{12}$

The setting for Soldiers of Fortune is closely modelled on the development of US mining interests on the south-east coast of Cuba, so this is very much a novel of Oriente. From 1880 onwards the Pennsylvania Steel Company developed mines along the Río Juraguá and built a railroad to take the ore to Santiago, from where it was shipped to Philadelphia. By 1898 Philadelphian steel firms owned eleven mines in the region, with an output averaging a quarter of a million tons a year. ${ }^{13}$

The revolutionary conflict of the 1950s brought a further wave of journalists to Oriente. Early in 1957 the Cuban government was trying to spread a story that Fidel Castro was dead. Castro had in fact been rebuilding his meagre forces in the Sierra Maestra and was now ready for a publicity coup. The US journalist, Herbert Matthews, was chosen for this and he drove all one night and most of the next day from Havana to the Sierra Maestra, to a safe house where Castro came to meet him, leading to the sensational story in the New York Times on 24 February 1957, which played its part in Cuba's revolutionary struggle, giving the lie to Batista's assertions of Castro's death. Matthews's piece started with the sentence: "Fidel Castro, the rebel leader of Cuba's youth, is alive and fighting hard and successfully in the rugged, almost impenetrable fastnesses of the Sierra Maestra, at the southern tip of the island". The adjective "rugged", poised between Castro and the Sierra, works to describe both. Oriente and Havana are at opposite poles: "The province of Oriente, with its two million inhabitants, its flourishing cities such as Santiago, Holguin, and Manzanillo, is shut off from Havana as surely as if it were another country". Oriente is a closed book to Havana, which means that neither Batista nor the US intelligence services know what is going on there: "No one in Havana, not even the United States embassy with all its resources for getting information, will know until this report is published that Fidel Castro is really in the Sierra Maestra". ${ }^{14}$ Oriente is associated with all the report's positive adjectives, and the contrast between the guerrilleros and Batista's soldiers is that, even though both groups are mostly outsiders to the area, the guerrilleros have made alliances with local people and have gained local knowledge, while Batista's soldiers have not and therefore do not have a sense of the place in which they are fighting.

\section{Guantánamo in particular}

Attention to place has to give weight both to actuality and to ideas. At different times and in different registers, places may gather particular associations which may have different levels of connection with actuality. Guantánamo offers an interesting current example. In actuality, Guantánamo is a city in Oriente with a not uninteresting cultural and literary history little known outside Cuba.

Guantánamo Bay is an important harbour, much but not all of which, for the last hundred years, has been under the control of the US Navy. However, in 2005, the resonance of what has happened to the

\footnotetext{
${ }^{12}$ Richard Harding Davis, Soldiers of Fortune [1897], New York, 1916, 30.

${ }^{13}$ For more on this see Peter Hulme, Rescuing Cuba: Adventure and Masculinity in the 1890s, Latin American Studies Center Series, no. 11, College Park, MD, 1996. On Soldiers of Fortune see Amy Kaplan, "Romancing the Empire: The Embodiment of American Masculinity in the Popular Historical Novel of the 1890s", American Literary History, 2 (1990), 659-90.

${ }^{14}$ Herbert Matthews, “Cuban Rebel is Visited in Hideout”, New York Times, 24 February 1957. See Matthews' account in his The Cuban Story, New York, 1961, 15-44.
} 
supposed enemy combatants held in Camp Delta has almost obliterated for the rest of the world any sense of Guantánamo as a Cuban city and Guantánamo Bay as a topographical feature. Guantánamo, tout court, now stands as the naval base with its resonances as a place of torture and illegal process.

Any larger literary historical project of the kind being sketched here would need both to recognise and situate those resonances and to provide that broader picture. As it happens, one of the most significant pieces of Cuban writing tells of a journey through Guantánamo Bay’s hinterland.

The literary movement known as siboneyismo stemmed from Oriente, where many indigenous towns were established in the eighteeenth century and where an indigenous population still survives today. Arguably, siboneyista writers have been condescended to by metropolitan literary criticism on account of their strong regional identities. An attention to place might bring a fuller appreciation of such writers. The better-known figure of José Martí is not usually seen in this connection: he was obviously a truly continental figure whose modernism makes him a cosmopolitan rather than a regional or provincial writer. Yet Martí's final and in many ways most powerful piece of writing is about Oriente and links him back to this very particular indigenous tradition.

The indigenous reference point was always present in Martí's writing. His most famous essay, "Nuestra América", has that classically American insistence that the continent is at its worst when it tries to imitate European appearance rather than seeking an appearance which corresponds to its own reality. ${ }^{15}$ The real sign of this failure of the Latin American intellectual class is, Martí says, in a very telling metaphor, the abandonment of their sick mother, a mother of whom they are ashamed, "porque lleva delantal indio". Martí's language is always dense and elliptical, but he often uses this kind of familial metaphor to talk about continental issues. "Nuestra" America, he says, has a carpenter for a father and an Indian for a mother, and the continent will make no true progress until it recognises that fact. And all Americans have these metaphorical parents, irrespective of their biological mother and father.

Six years before "Nuestra América" Martí had used another version of that familial metaphor to express his own identification with the Carib warriors who fought and died against Spanish invaders, writing of how one may descend from fathers of Valencia and mothers of the Canary Islands (as Martí himself did), and yet still regard as one's own the spilled blood of heroic Indian warriors. "La inteligencia americana es un penacho indígena," he wrote. ${ }^{16}$

Martí's last Cuban journey was across Oriente from east to west, from Las Playitas to Dos Ríos, near Bayamo, where he was killed on the afternoon of 19 May 1895. His Diario de campaña was written under conditions of extreme hardship while travelling over difficult terrain, constantly in fear of enemy attack. The writing is often almost impossible to read. The text was mutilated after its author's death and six pages are still missing. It was not published at all until 1940, and thereafter in inadequate and error-strewn editions until 1996 when a critical edition was finally published in Cuba.

Martí's journey across Oriente was a pilgrimage to a Cuban home from which he had been exiled for most of his life, an encounter with a countryside and people to which he had given his life, but which he had rarely visited. His writing is therefore in this dimension at its most American as he expresses the joy of contact with the natural world of the Cuban countryside, translated into writing through the often quite particularly Cuban words for certain trees or plants or dishes or places. The diary is marked by an almost obsessive accumulation of terms. Words for plants and objects, country cooking, peasant remedies, creole expressions: Martí's interest in and celebration of these terms turns the regional language of Oriente into the national language of Cuba.

But the linguistic point has another dimension. Some of the names of trees and plants and rivers and animals and household items are: najesí, bagá, yaya, cupey, yagua, yarey, jobo, pajuá, guayabo, jaraguá. Some of the places where Martí camped or otherwise refers to are: Cajobabo, Los Ciguatos, Malabé, Iguanabo, Yateras, Baraguá, Guantánamo. This is the creole language of Cuba and these are all Indian words. Some of the more sophisticated siboneyista poets had included these kinds of words in their writing, but as the language of exoticism. Martí touched the trees and the plants and the animals, and bathed in the rivers. During the last weeks of his life he lived a Cuban indigeneity.

\footnotetext{
${ }^{15}$ José Martí, “Nuestra América” [1891], in Obras Escogidas, 3 vols., ed. Ela López Ugarte and Adiala González Naranjo, Havana, 1992, II, 480-487, at 481.

${ }^{16}$ José Martí, “Autores Americanos Aboriginales” [1884], Obras completas, Havana, 1975, VIII, $336 .$.
} 
Martí himself was keenly aware of the Indian presence in Oriente, not least because Indians were originally employed as mercenaries by the Spanish to fight against the Cuban rebels, although the Indians later changed sides and fought with the rebels. In his diary, Martí writes of spending one of his last nights in the bohío of an Indian woman and her family, and he leaves behind a vivid sketch: "La mujer india... de ojos ardientes, rodeada de siete hijos, en traje negro roto, con el pañuelo de tocas atado a lo alto por las tranzas, pila café". ${ }^{17}$ So, here, just a few weeks before his death, Martí finds the American intelligence of an Indian headdress not where it might have been expected, in the Yucatán or the Andes or the plains of South Dakota, but on a woman hulling coffee in a small village outside Guantánamo. Cuban scholars have recently identified the woman as Gregoria Rodríguez. A few days before he died, Martí's long interest in the indigenous reality of the American continent culminated, surprisingly, in his native country, in Oriente, with the vision of a culture which, against all expectations, had survived to offer maternal succour to Cuba"s revolutionary heroes. ${ }^{18}$ Just before his death Martí famously warned of the territorial ambitions of the USA. The decade of the 1890s marks the beginning of that phase of US extra-continental expansion aimed at the remains of the Spanish Empire: one of the first targets would be Guantánamo Bay.

Decrepit as it was by the 1890s, the Spanish Empire had a number of features which made it particularly desirable to the USA, notably its original circumnavigatory ambitions, embodied in Columbus's thwarted attempt to sail more or less due west from Spain to Japan. By the end of the nineteenth century that truly tropical circumnavigation had finally become almost inevitable: a Central American canal would soon complete the process initiated by De Lesseps with Suez, and the USA would be able to establish for itself a world-wide commercial network supported by coaling stations on the Pacific tropical belt - Hawaii, Midway, Wake, Guam, Manila. ${ }^{19}$

These US global ambitions were first articulated by Captain Alfred Thayer Mahan, not much read nowadays, but a naval historian who became a close associate of Roosevelt's, and a writer whose theories of cultural conflict still find their neo-conservative echoes. Mahan had always judged the Caribbean to be essential for the development of US sea power, and Cuba to be the most desirable of the "island fortresses", as he called them, with unique positions and advantages. In a memorandum he wrote on behalf of the Naval War Board in August 1898, Mahan mentioned Guantánamo Bay, along with two other Cuban bays, saying "When Cuba becomes independent, the United States should acquire, as a naval measure, one of these ports, with a portion of adjacent territory". ${ }^{20}$ In fact, just before Mahan wrote those words, Guantánamo Bay had become the very first place in Cuba to see a US landing when marines put ashore there in June 1898 to prepare the way for the full-scale US assault on Santiago which followed later that summer and which more or less ended the USA's short war with Spain.

Under the terms of the infamous Platt Amendment which gave Cuba only nominal independence, the USA leased in perpetuity from Cuba land around Guantánamo Bay on which to build a naval facility. This naval base, GITMO, as its marine inhabitants charmlessly call it, has been in the news ever since 650 suspected Taliban and Al-Qaida fighters were brought there, first to Camp X-Ray and then to the newly-built Camp Delta. The building of a prison camp such as Camp Delta contravenes

\footnotetext{
${ }^{17}$ José Martí, Diarios de campaña, ed. Mayra Beatriz Martínez and Froilán Escobar, Havana, 1996, 86.

${ }^{18}$ The fundamental work here is by José Barreiro: “The Indian in Martí: American Indian Thinking and Issues in the Writing of the Cuban Apostle”, The Americas Review, 22/1-2 (1994), 148-167; and "Beyond the Myth of Extinction: The Hatuey Regiment” [22 paragraphs], KACIKE: The Journal of Caribbean Amerindian History and Anthropology [On-line Journal]. Available at: http://www.kacike.org/Barreiro.html [accessed 14.xi.2005].

${ }^{19}$ See D.W. Meinig, The Shaping of America: A Geographical Perspective on 500 Years of History, Volume 3: Transcontinental America 1850-1915, New Haven, 1998, 372-94. These outposts doubled as coaling stations and relay stations for submarine cables: the US victory over Spain in 1898 laid the foundations for global communication, even though the centre of that network remained, temporarily, in London. On US expansionism in the second half of the nineteenth century, see Walter LaFeber, The New Empire: An Interpretation of American Expansion 1860-1898, Ithaca, 1963, and Matthew Frye Jacobson, Barbarian Virtues: The United States Encounters Foreign Peoples at Home and Abroad, 18761917, New York, 2000.
}

${ }^{20}$ Alfred Thayer Mahan, Letters and Papers of Alfred Thayer Mahan, ed. Robert Seager II and Doris D. Seager, Anapolis, MD, 1975, 3 vols, II, 588. See Richard W. Turk, The Ambiguous Relationship: Theodore Roosevelt and Alfred Thayer Mahan, New York, 1987 and David McCullough, The Path Between the Seas: The Creation of the Panama Canal 18701914, New York, 1977, 250-257. 
Article II of the treaty by which the USA leases the land, which explicitly states that it should be used "as coaling or naval stations only, and for no other purpose" ${ }^{21}$ But this might be considered a minor legal infraction compared to the barbarous treatment of its prisoners, who remain in what a British court has described as a "legal black hole".

GITMO has a growing body of writing associated with it, most remarkably perhaps the powerful play, simply called Guantánamo, compiled by Victoria Brittain and Gillian Slovo from the testimony of judges, transcripts of speeches by politicians, letters from prisoners, which played in London and New York during 2004.

One implicit exchange focuses very direct on matters of place. At one point Donald Rumsfeld voices his infamous defence of conditions in Camp Delta:

just for the sake of the listening world, Guantanamo Bay’s climate is different from Afghanistan. To be in an eight-by-eight cell in beautiful sunny Guantanamo Bay, Cuba is not a - inhumane treatment. And it has a roof.

Everything that comes out of GITMO is filtered by US military censorship, which obviously proved impervious to the irony in a letter from one of the detainees to his mother. This is Bisher Al-Rawi, an Iraqi Muslim long resident in the UK, adding his paragraph to the literature of Oriente:

I'm writing to you from the seaside resort of Guantanamo Bay in Cuba. After winning first prize in the competition, I was whisked to this nice resort with all expenses paid. I did not have to spend a penny. I and Jamil are in very good health. The neighbours are very well behaved. The food is first class, plenty of sun and pebbles, no sand I'm afraid. ${ }^{22}$

Santiago de Cuba as a place of dark and forbidden pleasures, but also the exporting centre for the region's mining industry; Oriente's sierras as metonymic of revolutionary virtue, but also home to the island's surviving indigenous population; Guantánamo Bay as the place of the final education of Cuba's greatest writer into the creole realities of his country, but also the site of one of the greatest human rights abuses of our new century. Even taken together, the six examples offered here can only afford a very limited sketch of what the literary geography of Oriente might look like, let alone a literary geography of the extended Caribbean made up of twenty or more studies of such places. Nonetheless, the significance of place, with the particular resonance given here to that term, should be apparent.

\footnotetext{
${ }^{21}$ See “Texts of United States - Cuban Agreements and Treaty of 1934”: http://www.nsgtmo.navy.mil/gazette/History_9864/hisapxd.htm [accessed 10 November 2005].

${ }^{22}$ Victoria Brittain and Gillian Slovo, Guantanamo: 'Honor Bound to Defend Freedom', London, 2004, 35, 30.
} 